\title{
A abordagem "Histórias de vida em formação" como superação da dupla armadilha do conceito sem vida e da vida sem conceito ${ }^{1}$
}

La démarche " Histoires de vie en formation » comme dépassement du double écueil du concept sans vie et de la vie sans concept

\section{The "Stories of life in formation" approach as going beyond the double pitfall of the concept without life and of life without concept}

\author{
Alex Lainé*
}

\begin{abstract}
RESUMO
Este artigo pretende mostrar como realizar um processo eminentemente formativo, fundamentado em uma prática concreta de histórias de vida em grupo num contexto de formação. Por esses termos entendemos um processo por meio do qual cada narrador engaja-se em algo que lhe auto represente e que se transforma com vistas a aumentar o seu poder de aprender. Em paralelo, a visão de cada participante sobre o seu ambiente é modificada. As condições éticas, deontológicas e metodológicas necessárias para este tipo de trabalho são especificadas ao mesmo tempo em que o autor sublinha a importância da dialética que se desdobra entre a implicação individual de cada participante e o coletivo.
\end{abstract}

Palavras-chave: Histórias de vida. Formação. Ética. Prática e teoria. Subjetivação. 


\title{
RÉSUMÉ
}

En prenant appui sur une pratique concrète de récits de vie en groupe dans un contexte de formation, ce texte vise à montrer comment s'opère là un processus éminemment formateur. En entendant par ces termes un processus à travers lequel chaque narrateur engage quelque chose d'une représentation de soi qui s'y transforme dans le sens de l'augmentation de son pouvoir d'apprendre. Parallèlement, le regard porté par chaque participant sur son environnement, s'en trouve modifié. Cet écrit précise les conditions éthiques, déontologiques et méthodologiques requises par ce type de travail. L'auteur y souligne en même temps l'importance de la dialectique qui s'y déploie entre l'implication individuelle de chaque participant et le collectif.

Mots clés: Histoires de vie. Formation. Éthique. Pratique et théorie. Subjectivation.

\begin{abstract}
Based on a concrete practice of group life stories in a training context, this text aims to show how a highly formative process operates there. By understanding by these terms a process through which each narrator engages something of a self-representation which transforms itself in the sense of increasing his power to learn. At the same time, the way each participant looks at their environment is changed. This document specifies the ethical, deontological and methodological conditions required for this type of work. At the same time, the author underlines the importance of the dialectic that unfolds between the individual involvement of each participant and the collective.
\end{abstract}

Keywords: Life stories. Training. Ethics. Practice and theory. Subjectivation.

O propósito que segue sustenta que a abordagem "histórias de vida" em grupo é sempre um processo formativo, nem que seja apenas mediante a formação verbal e transmissível de uma trajetória de vida cuja estrutura e inteligibilidade não são dadas de antemão. Além disso, após o enunciado da história de vida, o trabalho analítico é feito coletivamente - de preferência a partir da perspectiva das perguntas que o narrador faz a si mesmo sobre a sua trajetória de vida - o que é sempre muito formativo. Especialmente quando ele consegue "superar" a dupla armadilha mencionada no título deste artigo, pois se o conceito sem vida é vazio, desprovido de sentido; a vida sem conceito é cega. Encontramos, nesse contexto, o projeto que orienta Henri Lefebvre em sua 
"Crítica da Vida Diária"2: "compreender o que é vivido, situá-lo e enquadrá-lo na constelação móvel de conceitos, explicá-lo dizendo o que implica, formulando assim o sentido da obra e do projeto..." (LEFEBVRE, 1981, p. 22).

A orientação metodológica e as escolhas teóricas nas quais se inscrevem minhas ideias são as da abordagem clínica ${ }^{3}$, se quisermos admitir que a orientação clínica não se reduz ao que se refere estritamente ao cuidado terapêutico, mas que, ao invés disso, é uma abordagem que se desenvolve "caso a caso" e é definida por uma ética de interação e co-elaboração entre um acompanhante e um acompanhado. Este último, longe de ser reduzido à função de um receptor passivo, toma parte ativa na elaboração do processo empreendido. Outra característica significativa da abordagem clínica consiste em reconsiderar as relações teórico-práticas, dando à primeira um lugar importante para que não se limite a servir de ilustração de modelos teóricos previamente concebidos, mas que esteja de fato na origem de elaborações teóricas inéditas. Por essa razão, partirei de uma prática de história de vida em formação que animei e que foi a fonte das análises metodológicas e teóricas relativas à questão da história de vida como processo formativo que proponho.

O que estamos avançando neste ensaio não é fruto de sonhos intelectuais, nem vem de uma simples leitura, mesmo que nos tenha servido bem. Nossas afirmações estão sempre ancoradas [...] em situações concretas. Elas expressam as reações dos proletários, rurais ou urbanos e da classe média que observamos; direta ou indiretamente, no decorrer de nosso trabalho pedagógico (FREIRE, 1974).

Na verdade, a abordagem das histórias de vida está agora bem estabelecida no campo da formação. Esses dispositivos - inclusive os acadêmicos - que consagram um espaço à narração das trajetórias de alunos não são mais excepcionais. É precisamente em um dispositivo de formação acadêmica e de graduação que se desenvolveu a prática em questão.

2 Tradução de "Critique de la vie quotidienne".

3 Do grego Klinikos que designa a postura daquele que se inclina ou se debruça sobre a cabeceira de um terceiro. 


\section{Uma prática de narrativas de vida em formação}

Esta abordagem ocorreu no âmbito de um curso de treinamento para assistentes sociais que se preparavam para o Diploma de Estado nas Funções de Animação $\left(\mathrm{DEFA}^{4}\right)$. O programa estabelecido pelos textos nacionais dessa formação previa uma unidade chamada Pedagogia e Relações Humanas (PRH), que previa espaço para o trabalho de implicação pessoal. O dispositivo local de formação começou com esta unidade, pela qual eu era responsável.

\section{A proposta de trabalho e o compromisso dos participantes: o pacto}

O pacto definiu-se pelas intenções a serem perseguidas, pelas modalidades deontológicas e técnicas da abordagem, assim como pelas instruções do trabalho proposto.

\section{As intenções a serem perseguidas foram as seguintes:}

- Conhecer-se e aprofundar o autoconhecimento.

- Trabalhar a relação com a profissão investigando a forma como cada um tornou-se animador sociocultural e como se vive e se representa essa profissão nos dias de hoje.

- Trabalhar a relação do indivíduo com o processo de aprendizagem e de conhecimento.

- Iniciar-se nas técnicas pertencentes à metodologia das ciências humanas e sociais.

- Trazer à tona os contornos de uma cultura e uma identidade profissional específicas para os profissionais que trabalham com animação sociocultural. $\mathrm{E}$, talvez, tornar explícitas as características desse gênero profissional. 


\section{Síntese dos objetivos éticos e as cláusulas deontológicas desejadas que orientaram este trabalho:}

Autonomia sob a forma de um trabalho voluntário dos participantes: como este é um processo de implicação pessoal, a fim de evitar o viés de um "público cativo" que seguiria este módulo não por escolha, mas por imposição externa de um programa pré-estabelecido, eu e meus colegas encarregados das unidades de treinamento posteriores colocamos em prática uma disposição especial. Oferecemos a cada participante potencial a escolha de participar ou não deste processo. Com isso, buscamos garantir que a participação fosse realmente voluntária. Portanto, antes da formação, apresentei individualmente a proposta de trabalho (intenções e modalidades da abordagem). Se um deles não quisesse participar, outro módulo de estudo, liderado por um de meus colegas, lhe seria oferecido. Implementamos essa abordagem em várias ocasiões e não houve nenhuma recusa em participar do trabalho proposto sobre as trajetórias profissionais e pessoais.

De modo mais geral, a questão do voluntariado dos participantes era crucial, pois condiciona a própria possibilidade da abordagem, estando em plena consonância com a orientação clínica já mencionada e garantindo o respeito à liberdade de cada participante, uma das principais preocupações e especificidades. Essa preocupação encontra outra de suas traduções no objetivo seguinte.

Autonomia em seu aspecto de "autogestão do próprio grau de implicação": muito concretamente, esse objetivo traduz-se na liberdade que cada participante possui para dizer e não dizer. Ninguém é obrigado a responder a uma pergunta que o envergonharia, assim como está garantido o direito de não apresentar um fragmento de sua história de vida em resposta a esta ou aquela instrução de preparação do suporte de trabalho.

Propriedade e confidencialidade das produções: tudo o que é dito neste módulo é estritamente confidencial. Ninguém está autorizado a divulgar informações relativas à história de um terceiro, partilhada durante a sessão. Todas as produções escritas, especialmente os textos autobiográficos, são e continuam sendo propriedades exclusivas dos seus autores.

Escutar atentamente e abster-se de qualquer intervenção ou postura na forma de um juízo de valor de natureza depreciativa em relação à história de vida contada por um participante: não interromper o curso de uma narrativa - a menos, é claro, que ela se revele, eventualmente, completamente inaudível ou ininteligível. Se houver dúvidas, serão expostas sempre após o fim do relato. 
Nessa perspectiva, o papel do instrutor que acompanha esse trabalho é essencial. Se, durante a narração de uma história de vida, uma intervenção ou mesmo uma atitude não verbal expressar um juízo de valor depreciativo em relação ao conteúdo do relato, o formador intervém para lembrar que cabe a cada um, sendo mesmo uma exigência, desenvolver uma escuta benevolente. Mais amplamente, qualquer um dos participantes pode pedir respeito a essa exigência. Na prática, trata-se de uma ocorrência rara. Na maioria das vezes, sozinhos, os participantes respeitam esse direito essencial.

Do ponto de vista geral da escuta - que é tema de verdadeiro aprendizado para os participantes durante as sessões -, além da mera decodificação do conteúdo verbal, a escuta dos corpos (aspectos não-verbais) é uma obrigação. Por "escutar os corpos", entendemos o que as vozes têm de natureza eminentemente material e corpórea: o timbre, o ritmo, a respiração e a postura do narrador, que fornecem informações imediatas sobre o estado emocional do interlocutor. Quando necessário, intervenho para dar ao narrador uma chance de se afastar, por exemplo, convidando-o a tomar seu tempo.

Co-elaboração de hipóteses relacionadas a todas ou a parte das narrativas partilhadas: a última palavra é sempre do narrador. Claro que, após cada narrativa, aqueles que ouviram sem interromper são convidados a dar, pelo menos, três formas de feedback. Inicialmente, os ecos para começar: objetivase que o ouvinte diga ao narrador o que o tocou durante a escuta da narrativa - mesmo que o evento tenha sido vivenciado de forma diferente por cada um. Trata-se mais de suscitar a implicação dos outros do que do narrador, conferindo a este último um bom espaço para respirar. Em seguida, os feedbacks podem se dar sob a forma de perguntas e de demanda por informações adicionais. Por exemplo, se um participante não tiver compreendido um elemento da história, ele pode pedir ao narrador um esclarecimento. Entretanto, o narrador pode se recusar a responder se a pergunta parecer intrusiva. Finalmente, e é nesta etapa que o trabalho e os conceitos mais teóricos são mobilizados, há um esforço para oferecer ao narrador, caminhos para a compreensão de sua história que lhe permitam, na maioria das vezes, conectar elementos que não estavam ligados previamente. $\mathrm{O}$ que se segue sobre a história de Fred e o conceito de hábito é um exemplo desta ligação e significado (cf. abaixo, § As contradições que habitam a relação entre escola e conhecimento - elas estão em parte ligadas à profissionalização).

O que resta são apenas propostas feitas ao narrador que, como tais, ele tem o direito de rejeitar. De toda forma, é o seu ponto de vista que prevalece. A análise de seu fracasso na escola em termos do hábito camponês que é proposto a Fred - como veremos mais adiante - só será retida porque lhe convém e ele concorda com a proposta. Além disso, é sempre recomendado que o narrador especifique, 
antes ou durante o curso de sua narrativa, se ele tem alguma dúvida em particular sobre seu passado. E os ouvintes são então convidados a explicar a perspectiva traçada durante o questionamento do narrador. O exemplo da narrativa de Fred, que será explicado mais tarde, é o de um narrador cujo questionamento visava entender por que ele não tinha tido sucesso em seus estudos universitários passados, apesar de um interesse muito manifesto pela reflexão e análise teórica. As explicações têm a peculiaridade de serem construídas coletivamente e com a contribuição ativa do narrador.

Deve-se notar que se as modalidades de trabalho estivessem em desacordo com alguns ou com todos os objetivos definidos no pacto, tal como já foi mencionado, poder-se-ia, então, ter certeza de que estaríamos caminhando para uma situação de violência e de guerra simbólicas. Esse seria inevitavelmente o caso se os ouvintes pudessem questionar a sinceridade de uma ou outra narrativa. Seria também o caso se os participantes não optassem explícita e livremente por participar deste tipo de trabalho fundado na implicação pessoal. Compreendemos que a escolha do termo pacto (aquilo que pacifica as relações) adquire então um significado importante face às interações que poderiam se dar de forma bem diferentes do pacifismo desejado.

\section{As modalidades técnicas do trabalho: uma abordagem de elaboração estruturada e progressiva das histórias de vida}

Inicialmente, tem-se um trabalho de preparação escrita individual obedecendo à seguinte instrução: "tornar-se um autobiógrafo". O objetivo é escrever uma apresentação sintética de si mesmo e que tenha pelo menos duas páginas manuscritas, sem estabelecer um limite máximo para o número de páginas. $\mathrm{O}$ interesse de produzir uma escrita breve e sintética é incentivar as pessoas a ir direto ao assunto. Aparentemente, a brevidade desta escrita reduz as inquietações daqueles para quem a escrita não é o modo de expressão preferido. Esse é frequentemente o caso dos animadores socioculturais.

As instruções convidam a que esta primeira escrita sintética seja, tanto quanto possível, estruturada em torno de três eixos ou perspectivas de exploração, que são tanto categorias temáticas, quanto conteúdo que será utilizado nas análises. Portanto, não se trata de um questionário, mas de um guia de trabalho que os participantes são livres para usar, cada um à sua maneira e, às vezes, não levando em conta algumas das pistas de exploração que são propostas. Os quatro eixos de pesquisa autobiográfica são os seguintes: 
A perspectiva do conhecimento das origens profissionais. Nesse ponto, o autobiógrafo tenta lembrar a forma como ele "entrou na animação" sociocultural. A formulação é carregada de uma conotação religiosa. Existem, é claro, movimentos religiosos de Educação Popular. Mas, de modo geral, e apesar de certas oposições, existe uma analogia entre o campo da animação sociocultural e o da religião. A "vocação", referida tanto em um campo como no outro, é um indicador dessa proximidade. A etimologia do termo "animar", do latim "anima" = alma, também milita nesse sentido.

Em outras palavras, todos são convidados a especificar como aconteceu a entrada na animação: em que contexto, em que momento, a partir de quais experiências e atividades, com base em que valores militantes, ideológicos, qual foi a força motriz ou desencadeadora?

A perspectiva de experiências "marcantes". Em geral, e indo além do contexto da animação sociocultural - ainda que possa ser bastante abrangente - quais são as experiências de formação, de profissão e, mais amplamente, as experiências de vida que cada pessoa retém como marcantes em sua jornada pessoal? Em que consistem essas experiências? E de que forma eles desempenharam um papel significativo (positiva ou negativamente)?

O lugar do diploma e da formação neste processo: como chegamos lá e que projeto(s), eventual (is), se houver, estamos buscando? Uma vez que cada participante tenha escrito sua breve autobiografia, eles são convidados a se reunirem em subgrupos de três pessoas. Cada um, em sua vez, conta aos outros dois sobre a sua trajetória, com base no texto que eles escreveram anteriormente. No final de cada narrativa, os colegas ouvintes dão feedback ao narrador, conforme descrito nos parágrafos anteriores. No final desta fase de trabalho em grupos de três, cada narrador volta ao seu texto inicial, levando em conta o feedback recebido.

A fase de trabalho em pequenos grupos de três tem várias funções, uma delas é facilitar o processo de fala, tendo em mente que estamos no início da formação e que falar em frente a um grande grupo de 15 pessoas é bastante intimidante. No entanto, a narração de cada história no grande grupo será o tema da próxima fase.

Nesta etapa, cada pessoa apresenta o que reteve como representativo da sua trajetória pessoal e de seus projetos. Essa fase obedece às exigências de escuta definidas pelo pacto e, ao mesmo tempo, inicia o trabalho de análise de conteúdo, que permite, antes de tudo, identificar o que é específico em cada história e em cada trajetória. Em seguida, chega-se ao que, nas categorias temáticas que correspondem às três perspectivas de exploração autobiográfica, é transversal ou comum às diferentes narrativas enunciadas. Esse trabalho de análise de conteúdo é desenvolvido coletivamente. Finalmente, a partir das anotações 
feitas ao longo da análise transversal, redijo um relatório que será entregue a cada participante. Esse relatório trata exclusivamente de questões transversais, ou seja, as características comuns às histórias de vida de vários membros do grupo. São também comuns às trajetórias de muitos outros facilitadores, de modo que são perfeitamente impessoais e anônimos.

\section{A análise transversal das histórias de vida pessoal e profissional dos animadores}

Os três parágrafos iniciais do texto a seguir foram dados aos participantes da formação de 1995 a que me refiro. Esse texto é o traço do trabalho de formação que os participantes realizaram comigo seguindo as narrativas de suas trajetórias.

A análise em questão retoma e reúne os resultados das dez práticas desta abordagem que realizei com animadores socioculturais. Quais são então os pontos de interseção entre estas narrativas?

\section{O homem está na sociedade, mas a sociedade está também no homem}

Primeira transversalidade que merece atenção: nenhuma das existências relatadas ocorreu em um vazio social e histórico. Pelo contrário, todas elas mostraram a ancoragem das trajetórias narradas em um contexto que as influenciou e as marcou profundamente.

Entre fatos sociais e históricos decisivos estão, em algumas das histórias, a crise do mundo camponês e o êxodo rural que afetaram mais de uma família, às vezes até mesmo antes do nascimento do narrador. Por vezes, descobre-se que, enquanto os pais deixaram a terra contra a vontade, o filho ou a filha embarca na "carreira" de um animador sociocultural em uma associação para a defesa e promoção da cultura rural. É como se a criança assumisse então a lesão e o desejo de reparação que ouviu dos seus pais.

Outras ancoragens das trajetórias individuais e das escolhas profissionais e/ou militantes no contexto social e histórico são baseadas em eventos experimentados direta e pessoalmente pelos narradores. Esse é o caso da luta de classes e do trabalho de fábrica. 
Alguns facilitadores já experimentaram isso. Ex-trabalhadores, ativistas sindicais, engajam-se em um processo de conversão profissional que, antes de tudo, lhes permite distanciar-se da fábrica - "a prisão" - como um deles a chamou. Ao mesmo tempo, a nova profissão permite preservar algo da militância de suas origens. Esse é um exemplo do sofrimento no trabalho e da erosão de identidade de uma profissão praticada no passado.

Há várias razões para destacar este tipo de ancoragem. Antes de tudo, é precisamente este tipo de ancoragem que ilustra o que foi anunciado acima. É certamente útil, em um momento em que se desenvolve uma representação individualista dos fatos humanos, lembrar que os indivíduos e sua história não flutuam em um vazio social e histórico. Pelo contrário, essas histórias estão inscritas nos processos que as envolvem e influenciam a trajetória desses indivíduos. Se usarmos a metáfora da flutuação, pode-se dizer que lembrar desta inscrição nos fatos sociais e históricos dá aos sujeitos um pouco mais de consistência, densidade e peso social. Há certamente efeitos de desenvolvimento pessoal da análise (no sentido de mediação entre o que é terapêutico e o que é formativo) que lembra a influência dos fatos sociais sobre as histórias individuais, pois ela revela os traços pouco desconhecidos nos quais estamos inscritos e as múltiplas filiações que nos ligam ao mundo e a outros.

Em contrapartida, por vezes, observa-se algum incômodo em descobrir ou redescobrir esses pontos de ancoragem. Esta característica exige a mesma cautela por parte dos ouvintes da narrativa, a mesma preocupação e prudência em respeitar os limites da capacidade do narrador de ouvir o que lhe é dito sobre a sua história, quando se trata mais de aspectos psicológicos. Essas filiações, pertencimentos e legados nem sempre são experimentados como gloriosos, fontes de orgulho. Então sua lembrança, ou mesmo sua revelação, sempre debilita a forte ilusão individualista que consiste em pensar que nós nos construímos sozinhos e que não devemos nada a ninguém. Trata-se da questão do sentido da escolha profissional atrelada a processos de herança que sublinham o fato de que no processo de escolha de uma profissão - escolha que parece ser muito pessoal e individual - estão presentes fatos coletivos e mundos sociais.

\section{As contradições que habitam as relações com a escola e com o saber (em parte ligadas à profissionalização)}

Em primeiro lugar, parece que a trajetória escolar dos animadores socioculturais e sua formação inicial raramente são marcadas pelo sucesso 
absoluto. Pelo menos no que diz respeito à perspectiva "bancária" de obtenção de diplomas. Em alguns casos, podemos até falar de fracassos que produziram como consequência um direcionamento para uma área técnica, orientações recebidas quando o narrador era aluno e que foram frequentemente sentidas como dolorosas e constrangedoras.

Em relação a esse primeiro elemento, as narrativas das trajetórias revelam em grande parte uma forte hostilidade em relação ao mundo da escola, aos professores e aos métodos que eles utilizam. Eles são acusados de utilizar métodos pedagógicos arcaicos, de estar presos a conteúdos disciplinares e currículos pré-estabelecidos e de serem "burocratas" submissos a uma instituição exigente e repetitiva, que impede a inovação e bloqueia o interesse dos alunos.

Eles são criticados por serem "funcionários públicos" que se recusam a ir além do horário legal de trabalho quando a situação exige. Esse tipo de representação - como seria de se esperar - não facilita as relações. E isso é tanto mais prejudicial quando os animadores socioculturais são levados a trabalhar em parceria com o mundo docente através de uma combinação entre ajuda com a lição de casa, atividades extracurriculares e outros projetos educacionais locais.

Tudo isso define o "polo negativo" ou hostil da contradição - não seria exagerado, em alguns casos, falar de "ódio". Mas há um lado oculto, um polo "positivo" na contradição. E certamente não seria escandaloso falar de "amor" dos animadores pelo mundo da escola e do conhecimento. Em primeiro lugar, porque quando vamos um pouco mais longe na história de vida, muitas vezes aprendemos que o narrador em questão, antes de abraçar a profissão de animador, tinha como um projeto, como um sonho, tornar-se um professor. Foram precisamente as dificuldades encontradas na escola que impediram esse projeto. E de certa forma, o trabalho de animador possibilita o retomar as práticas pedagógicas (ajuda na lição de casa, animações extracurriculares, ações de formação, etc.), o que obviamente leva à rivalidade com o mundo escolar. Em seguida - e este não é o menor elemento que torna o mundo do ensino atraente - não é raro que as narrativas mencionem, para além de professores considerados execráveis, um professor "bom", muitas vezes um ativista da Educação Popular, promotor de métodos de ensino novos e ativos. Esse mesmo professor "modelo" que, em alguns casos, desempenhou, para aquele que foi, antes de tudo, um aluno, o papel de "transmissor" da profissão de animador.

Para além do fato de que esta revelação de sentimentos ambivalentes em relação ao mundo da escola é útil para aqueles que são levados a colaborar frequentemente com professores, ela não é desprovida de significado no momento em que o indivíduo entra em um dispositivo de formação, no qual o conhecimento e a aprendizagem se darão junto a um formador do sistema de Educação Nacional. 
A fim de esclarecer do que estamos falando, segue abaixo um fragmento de uma das narrativas após a realização do trabalho de análise coletiva. Trata-se da história de Fred ${ }^{5}$ segundo a "perspectiva das experiências marcantes" e que foram tratadas na formação. Falando das suas dificuldades na universidade, Fred disse:

Eu estava convencido de que não estava no lugar certo, porque não tinha a percepção do que a teoria pode trazer. E assim eu matava as aulas. No entanto, onde aprendi muito foi na prática. Como eu não tinha muito dinheiro, trabalhei nos mercados como vendedor. Lá aprendi como ser engenhoso, como encontrar o lugar certo para minha banca, como me dirigir a um cliente potencial para obter sua atenção, etc.

Ao ouvir essas palavras, muitos outros participantes, da classe trabalhadora e do campesinato pobre, identificaram-se com a experiência relatada. Eles a conheciam. O grupo e o formador se apegam então ao sentimento de "não pertencer" à universidade que Fred diz querer trabalhar. E como seus comentários anteriores haviam revelado na sua história de vida uma longa tradição de camponeses pobres (bisavós, avós, pais), tanto do lado paterno, como materno, levantamos a hipótese de que os dois fenômenos provavelmente não sejam totalmente independentes. Propôs-se, então, como uma pista de compreensão possível que possa existir uma marca do habitus (BOURDIEU, 2000) do mundo rural, ligado ao trabalho da terra, para o qual a atividade concreta e útil é o valor central, enquanto a cultura acadêmica é vivida como uma cultura estrangeira, associada ao luxo de um "sonho vazio", ou mesmo ao exercício do poder pelos dominantes sobre os dominados. Essa hipótese será confirmada por Fred, que esclarece o que ele disse sobre professores universitários, considerados como pessoas da cidade, funcionários públicos, dedicados a atividades de "falinhas mansas", sem controle efetivo sobre a realidade e inclinados a exercer poder sobre as "pessoas pequenas" para "diminui-las" com suas "palavras bonitas", para usar as palavras exatas de Fred.

Fomos ainda mais longe e nos perguntamos se estávamos diante de uma fatalidade. Estamos condenados, quando internalizamos estas representações e valores sociais que se desenrolam sem que tenhamos consciência disso, a reproduzir a posição que herdamos e, falando sem rodeios, a ser incapazes

5 Fred autorizou-me explicitamente a tornar pública suas ideias. O pacto firmado com os participantes desse trabalho dá continuidade ao meu engajamento. 
de aprender? Os desafios dessa pergunta eram altos para os participantes que estavam no início de um curso de três anos.

A resposta dada foi: o provável nunca esgota completamente o possível e o hábito que um sujeito carrega não o condena definitivamente a conformar-se aos valores que ele contém, tanto mais se este hábito e seus efeitos sejam objetos de uma atualização, de uma conscientização e de um trabalho. Ao fazer estas observações, introduzimos um senão na perspectiva determinista e um pouco fatalista da sociologia da reprodução social, para significar que há sempre espaço para uma liberdade do sujeito dentro do determinismo social. Voltarei a este ponto para concluir. Hoje, Fred, com quem mantenho contato, obteve brilhantemente seu DEFA, realizou estudos universitários em planejamento territorial, obteve um mestrado 2 nesta disciplina e recentemente engajou-se em um trabalho de tese. $\mathrm{O}$ que não deixa de ser interessante, tendo em vista o que foi exposto nos parágrafos precedentes.

\section{Terceira transversalidade: a natureza tênue da fronteira entre vida pública (profissional e vida privada)}

A proximidade, até mesmo a confusão entre essas duas esferas da existência, está inscrita no tempo e no espaço. Os animadores socioculturais, pelo menos na França, trabalham principalmente à noite, nos fins de semana $\mathrm{e}$ durante as férias escolares. Isso significa que eles trabalham em momentos em que outros não trabalham. Além disso, não é raro, sobretudo quando estão em posições gerenciais, que sejam alojados no estabelecimento onde trabalham, de forma que os espaços privado e profissional acabam se confundindo. Essas situações são vividas como uma fonte de cansaço e desgaste produzida pelo trabalho. A entrada em um dispositivo de formação, a fim de se preparar para um diploma profissional, é frequentemente associada ao desejo de sair da confusão entre a esfera privada-pessoal e a esfera pública-profissional. A formação é, de fato, uma forma de obter acesso a um diploma, ou seja, a um estatuto preciso e a condições de trabalho - acordos coletivos, horários, duração, respeito aos feriados, etc. - permitindo reivindicar uma melhor separação das duas esferas pública e privada.

Finalmente, a ausência de fronteiras entre a vida privada e pública é parte da contradição mais geral do trabalho dos animadores, que ficam tensionados entre dois polos e dois personagens: o profissional e o militante (MEISTER, 1972). 


\section{A contradição da relação com a profissão: a animação entre militância e profissionalismo}

O caminho clássico do animador, tal como ele é mencionado nas narrativas que são contadas, é o seguinte: da vocação às férias. De usuário dos serviços de lazer oferecidos por uma associação quando criança ou adolescente, ele se torna um militante e um animador voluntário. Em seguida, uma oportunidade de trabalho durante as férias lhe é oferecida e, finalmente, um contrato de trabalho em tempo parcial ou integral. Muitas vezes esse processo ocorre dentro da mesma associação. De toda forma, o que está presente e expresso na narrativa de vida é um processo que inclui uma dimensão de compromisso militante e psíquico e uma dimensão ou aspiração profissional. A coexistência destas duas dimensões não é evidente por si mesma.

O engajamento nessa profissão é sustentado por opções ideológicomilitantes e por processos psicológicos que envolvem profundamente a identidade. Trata-se de um compromisso baseado em diversos valores ideológicos: o cristianismo social e "progressista", o marxismo, a moral da solidariedade com os mais desfavorecidos, as ideias de Jules Ferry em favor do acesso a um maior conhecimento, à cultura e, consequentemente, ao poder, etc. Além disso, não é raro que esses valores tenham sido herdados dos pais um pai que foi um militante sindical, por exemplo - ou transmitidos por uma figura de influência, tal como foi mencionado em parágrafos anteriores. Esse "influenciador" muitas vezes desempenhou um papel crucial no nascimento da "vocação". Como figura de identificação determinante, muitas vezes é ele quem irá propor ao futuro animador que ele se torne um voluntário, depois um profissional, recrutando-o para a equipe que ele está supervisionando e transmitindo sua "paixão" pela animação. Assim como em outros lugares, o que é transmitido do formador ao estagiário é, antes de tudo, o amor pelo assunto ou pela prática social que está sendo ensinada.

Esse fenômeno, destacado em muitas narrativas, é complexo e merece ser esclarecido, pois na origem da vocação profissional se descobrem valores militantes, amor e identificação.

No primeiro polo de entrada na animação sociocultural encontramos precisamente a vocação que repousa tanto em fatores sociais e ideológicos os valores militantes já mencionados - quanto em processos psicológicos de identificação com uma pessoa carismática. Este carismático "influenciador" é uma espécie de "mediador" que garante a passagem entre o status de usuário e o status de voluntário ou profissional. 
Através desse processo de identificação, obtém-se um duplo reconhecimento. O primeiro é o reconhecimento pelo futuro animador do "influenciador", que é o objeto da identificação. Em seguida, trata-se, acima de tudo, do reconhecimento do futuro animador pelo "influenciador" que lhe propõe tornar-se um militante e depois um profissional. Esse segundo processo de reconhecimento deve ser ainda mais enfatizado, pois muitas vezes diz respeito a sujeitos cuja autoconfiança é relativamente baixa.

Essa característica relaciona-se ao que foi mencionado anteriormente sobre a complexa relação com a escola. Em muitos casos, para esses futuros animadores, a história escolar é marcada por dificuldades, mesmo fracassos, acompanhados por uma autoimagem não muito positiva, um sentimento de não ser muito capaz intelectual e profissionalmente. $\mathrm{O}$ mundo da animação será aquele em que se sentirá reconhecido como capaz, digno de exercer responsabilidades. Essa confiança em um terceiro será a fonte de uma relação com a estrutura empregatícia - e mais geralmente com a profissão - marcada por um forte investimento emocional e uma certa dependência.

De toda forma, este modo de investimento certamente contribui para a produção de uma representação vocacional da profissão. Pode-se falar da descoberta da animação como uma "revelação", por exemplo: "não considero a animação como uma profissão, mas como minha vida". E, como se diz em francês: quando se ama, não se conta. Portanto, não é surpreendente ver os animadores sacrificarem - no sentido forte e religioso do termo - suas vidas (privadas) a esta missão que eles consideram ser muito mais do que uma profissão.

No outro polo da relação com este setor da vida social, está a aspiração profissional fortemente presente nas histórias de vida dos animadores como uma tentativa de lidar com o outro lado da moeda da militância. A profissionalização aparece como uma tentativa de lidar com a natureza contraditória do investimento militante que gera prazer de fazer o que se gosta, mas sem ter como contrapartida um limite. O resultado: uma falta de fôlego. Não se consegue durar muito tempo se o tempo e esforço não forem contabilizados. Encontra-se assim a dialética da paixão: da realização do desejo que o sujeito carrega, que gera um sentimento de liberdade em seu trabalho, pois ele faz o que ama ("faço um trabalho que me agrada, que me fascina", "não é um trabalho, é minha vida"), a um constrangimento do qual ele padece (a paixão é também o sofrimento de Cristo) ${ }^{6}$

Essa forte imposição é perceptível e frequente em certas afirmações, por exemplo: "Preciso respirar, relaxar e me afastar do ativismo do trabalho". É

60 verbo "padecer" (que significa sofrer) tem a mesma etimologia da palavra "paixão". Todos os dois vêm do grego "pathos". 
precisamente a aspiração profissional que tenta sair desta imposição. Para a qualificação profissional, o DEFA dá acesso a um status que é acompanhado por acordos coletivos que introduzem as limitações necessárias. Além disso, a aspiração à profissionalização também atende às exigências do campo e dos parceiros na ação socioeducativa e sociocultural, que estão cada vez menos satisfeitos apenas com a boa vontade, mas exigem habilidades técnicas devidamente validadas.

Diante disso, deve-se acrescentar que existe tensão entre os dois polos da militância e da profissionalização. A transição do primeiro para o segundo não é isenta de dificuldades. Ou melhor, não nos movemos de um para o outro, ficamos em ambos ao mesmo tempo. E esse é o problema. Aspira-se por mais profissionalismo, mas sem querer perder a dimensão militante. A tensão dialética entre estes dois polos toma contornos, muitas vezes ouvidos no decorrer deste trabalho de "história de vida", do sentimento de culpa sentido ao chegar à formação DEFA. Esta formação faz obviamente parte do processo de profissionalização, ou seja, da aquisição de uma competência validada (e validante). Ao mesmo tempo é vivida como um abandono da equipe na qual se trabalha, da qual se faz parte. Por exemplo, afirma-se que enquanto um está em formação (uma semana por mês) a parte do trabalho de um "cai no colo" dos outros. Há até mesmo algo como um sentimento de traição, que remete à conviç̧ão que se sente - juntamente com a equipe à qual se pertence - de estar investido de uma missão social, cuja necessidade imperativa não tolera a deserção de um de seus membros, nem o adiamento para mais tarde. Além disso, quando essa equipe está na origem do ingresso na profissão, quando ela depositou, pela primeira vez, uma confiança no futuro líder, então o sentimento de estar "em débito" e de trair ao começar a formação é ainda mais forte, sobretudo porque a lógica da profissionalização através do diploma DEFA é a da mobilidade profissional, da mudança do tipo de responsabilidade e, consequentemente, da mudança frequente de empregador. Uma vez qualificados, se eles quiserem trabalhar à altura da qualificação conquistada, terão que ir para outro lugar, para uma estrutura de trabalho que seja maior ou que corresponda mais de perto a suas novas qualificações. Tudo isso está em contradição com a forte dependência que o vincula à "estrutura-mãe", aquela que se experimenta como tendo "lhe dado uma chance".

No momento em que esse sistema de contradições emerge, sempre me lembro das análises de "O controle da organização sobre o empregado" (PAGÈS et al., 1984). No que diz respeito às "empresas hipermodernas", este vínculo

7 Tradução de “L'Emprise de l'organisation sur le salarié". 
é descrito e analisado como um vínculo de dependência afetiva que reproduz a dependência da "mãe arcaica". Tal vínculo de dependência e amor - mesmo que não seja diretamente identificável como sendo o que une o animador à sua associação - merece ser evocado porque permite compreender como o poder e a exploração podem "segurar" sem que aqueles que padecem se deem conta. É precisamente este vínculo de dependência emocional que cumpre uma função de filiação, de "colonização interna", de tal forma que o poder não é imposto de fora. Pelo contrário, a dependência age no interior dos sujeitos sobre os quais exerce influência, fazendo com que se sintam culpados, até mesmo envergonhados e pessoalmente invalidados, quando tentam se livrar dela.

No segundo caso (da empresa hipermoderna), a atitude dominante é a adesão, evitando desvios, cujas molas são a gratificação e desvantagem (que simbolicamente se referem à oferta e à ausência de amor da mãe) (PAGÈS et al., 1984, p. 172).

Trata-se das condições psicológicas de funcionamento de uma estrutura profissional. Neste ponto, é bastante interessante observar que as empresas, através de "projetos e outras culturas corporativas", tentam criar essa associação, esse forte elo que é prerrogativa do campo associativo militante. Ainda com o objetivo de ligar as descobertas empíricas aos conceitos que podem ser alimentados mutuamente, apresento também as teses de Marcel Mauss sobre a natureza contraditória do "dom”. Mauss (1993) define a instituição do dom como uma realidade que satisfaz o receptor e ao mesmo tempo o "obriga" a entrar em uma relação de subordinação em relação ao doador. Com o dom, trata-se antes de tudo de uma questão de receber. Mas, em seguida, de "retribuir", restando a questão acerca da forma pela qual se pode retribuir.

Uma parte considerável da nossa moral e da nossa própria vida está sempre estacionada nesta mesma atmosfera do dom, da obrigação e da liberdade misturadas... (...). O dom não devolvido torna aquele que o aceitou ainda inferior [...]. Mesmo práticas recentes e engenhosas, como os fundos de assistência às famílias que nossos industriais franceses desenvolveram livre e vigorosamente em favor dos trabalhadores com família, respondem espontaneamente a esta necessidade de vincular os próprios indivíduos... (MAUSS, 1993, p. 258-261). 
Finalmente, pode-se acrescentar que a tensão entre voluntariado-militância de um lado e profissionalismo do outro não se limita ao conflito intrapessoal vivido e expresso pelos animadores. É uma das principais fontes dos conflitos agudos que surgem nas instituições socioeducativas ou socioculturais e que se opõem aos voluntários militantes, por um lado, e aos profissionais, por outro. Os primeiros acusam os segundos de não serem mais militantes, de comportarem-se como "funcionários públicos" e de contarem seu tempo (as mesmas reprovações que os animadores fazem aos professores!). Por outro lado, os últimos censuram os primeiros por serem incompetentes, o que não ajuda e resulta, por vezes, em demissões (PEYRE, 2005) ${ }^{8}$, pois os ativistas voluntários são, nas estruturas associativas, os empregadores dos profissionais.

\section{Conclusão. A história de vida em formação: um processo de subjetivação como construção ou reconstrução das subjetividades}

A subjetividade é a maneira pela qual o sujeito experimenta a si mesmo em um jogo de verdade no qual ele se relaciona consigo mesmo (FOUCAULT, 1994) .

Conhecimento de si e transformação da relação com o saber

Acima de tudo, a abordagem "histórias de vida" modifica o conhecimento que cada pessoa tem da sua história e de si mesma por meio do trabalho da memória, que traz à tona toda uma série de experiências, se não totalmente esquecidas, pelo menos enterradas no fundo dessa memória. Frequentemente, a narração de uma pessoa provoca e aciona as lembranças nos demais. Esses são os processos de eco, aos quais voltarei posteriormente.

8 Começamos a entender que o mundo associativo não é isento de conflitos de trabalho e de assédio profissional. Obra que conta com um prefácio escrito por Christophe Dejours (2005) e em resposta a um pedido da CGT, em testemunho.

9 Do artigo de Michel Foucault no "Dictionnaire des Philosophes” (Dicionário dos filósofos) de Denis Huisman (1984) redigido por Foucault sob o pseudônimo de Maurice Fleurance (M.F., como Michel Foucault) e publicado por Foucault em "Dits et écrit"s (Ditos e escritos), 1994. 
De um ângulo mais qualitativo, estamos claramente tratando de um processo de autoformação (PINEAU; MARIE-MICHÈLE, 1983), que não é exatamente autodidatismo, mas um ato solitário de formação. No caso das narrativas de vida em grupo, pode-se dizer que o processo de formação é "solidário" na medida em que o outro ou os outros - enquanto acompanhantes - participam intensamente. Acima de tudo, porém, deve-se insistir na estreita relação entre experiência e conceito. Elementos teóricos e modelos - incluindo os acadêmicos - são propostos apenas na medida em que parte ou a totalidade da história contada pelo narrador é esclarecida. Entre as consequências diretas desta relação está uma experiência de conhecimento que não tem muito a ver com o aprendizado escolar. No caso da história de Fred, o conceito de hábito e seu papel determinante assumem todo um significado ${ }^{10}$ porque ajudam a compreender a experiência do narrador, levando-o a olhar para ela de uma maneira diferente. Nesse momento, é frequente observar uma verdadeira reconciliação com o conhecimento dos alunos, que nomeio de "os zangados com a escola", porque eles são inicialmente os portadores de uma experiência de fracasso no processo de aprendizagem em um ambiente formal onde não perceberam o significado do conhecimento oferecido. Essa reconciliação não funciona apenas para o narrador, cuja experiência vivida é o objeto da análise proposta, mas também para os outros que escutam e cujo caminho de formação pessoal muitas vezes contém experiências semelhantes. Dito de outra forma, existem fenômenos de "eco" muito fortes que se traduzem pela ressoar de uma história na outra, de modo que o que esclarece a experiência de um lança luz sobre a de outros.

\section{Reconhecimento de si}

A relativa transformação do autoconhecimento está associada a uma mudança no auto reconhecimento. Mais especificamente, cada narrador, durante e no final de sua história de vida, sente e sabe que é mais reconhecido. A escuta aberta e empática, a recepção atenta de cada narrativa é em si um ato de linguagem (AUSTIN, 1970), o que significa para o narrador que "O que você diz sobre sua história, ou seja, sobre você mesmo, é do nosso interesse". Esse processo de reconhecimento pelos outros é ainda mais forte quando o narrador frequentemente começa sua narrativa com as palavras: "Eu não tenho muito a dizer e ninguém provavelmente estará interessado no que eu tenho a dizer!’. Em resposta, a pessoa terá uma escuta silenciosa e quase religiosa da sua história. Em seguida, ela ouvirá o feedback dos seus pares, uma espécie de eco da sua

10 Entendido como o que confere inteligibilidade e valor a um objeto de saber. 
própria história. Ela também receberá, em resposta às perguntas gentilmente transmitidas ao grupo, propostas de explicações ou de correlações entre os eventos da sua história com a dos demais. A qualidade deste feedback a informa sobre o grau de compreensão e de atenção que foi dado à sua narrativa; este é um ponto importante, se nos concentrarmos na relação com o conhecimento. A história de Fred é testemunha disso. O feedback que ele recebeu para explicar, ou melhor, para entender porque ele sentia que não pertencia à universidade e porque desistiu, ajudou-o a recuperar a confiança em sua capacidade de aprender. Não é a mesma coisa dizer a si mesmo que não aprendeu porque foi estúpido e/ou preguiçoso, e entender que é o resultado de uma determinação social e cultural que atribui um valor negativo ao saber teórico e não inclui o conhecimento da pessoa em questão. Algo do nível da autoconfiança conserta-se então no processo de aprendizagem.

Enfim, um outro elemento irá contribuir para o auto reconhecimento. Apesar do processo trazer à luz várias influências vividas no decorrer de sua vida, o narrador revela-se como tendo sido pelo menos um agente ativo em sua história. Ou seja, mesmo quando ele foi determinado a agir nesta ou naquela direção por forças inicialmente externas a ele, ainda é ele quem agiu para que este determinismo fosse realizado. A narrativa de Fred e o momento em que ele decide faltar às aulas, percebendo assim algo do hábito do mundo social ao qual ele pertence, testemunha isso. E como nem tudo na vida é totalmente determinado, há também momentos em que o narrador se revela mais como um sujeito-ator do que como um mero agente da sua história. Esses são os momentos em que, por sua própria iniciativa, ele toma medidas decisivas, indo às vezes contra o fluxo dos determinismos que são exercidos sobre ele.

A auto-estima é o momento reflexivo da práxis: é ao apreciarmos nossas ações que nos apreciamos como autores e, portanto, como algo mais do que meras forças da natureza ou meros instrumentos (RICOEUR, 1990, p. 208.)

O exemplo que me vem à mente para ilustrar essa ideia é o da pessoa que eu chamo de "neta simbólica do padre Pierre". Durante o inverno de 1954 - um inverno particularmente rigoroso na França -, o padre Pierre ficou conhecido do público em geral ao fazer seu famoso discurso contra a incapacidade dos governos de encontrar soluções habitacionais para os "sem-teto", que eram numerosos e particularmente vulneráveis em tempos extremamente frios. 
Foi nesse ano que, junto com os companheiros de Emmaüs ${ }^{11}$, ele acolheu e encontrou abrigo para uma mulher que vivia na rua (dentre outras pessoas que ele ajudou). Uma vez que essa mulher estava relativamente integrada socialmente graças à ajuda recebida, ela engaja-se com os companheiros de Emmaüs. Por sua vez, ela teve uma filha que terá quase a mesma trajetória da sua mãe e que terá também uma filha. A avó e a mãe terão um projeto forte e decisivo para essa neta. Sabemos que quando os pais têm um projeto que eles mesmos não conseguiram realizar, esse projeto se torna o destino dos seus filhos. E isso é o que vai acontecer. A mãe e a avó querem absolutamente que a filha vá à escola para se tornar, nesta linhagem, a primeira a cursar o ensino superior e formar-se como advogada para defender... os pobres e os sem-teto. O projeto é uma modalidade de determinismo. A jovem passa por isso, passa pelo vestibular, vai para a faculdade de direito, torna-se advogada e... quando ela vai para a prática, decide se tornar uma advogada de negócios para defender pessoas ricas, provavelmente para ganhar dinheiro. O que retenho desse caso é que, mesmo dentro de um forte determinismo, há espaço e margem para o exercício da liberdade do sujeito-ator. Dito de outra forma, a história de uma vida nunca é totalmente determinada de fora e nunca é totalmente determinada ou inteiramente livre. São os dois ao mesmo tempo. Esta autoconsciência como capaz de influenciar o curso da vida é a primeira condição do processo de historicidade que será discutida a seguir (§ 4.).

Para nós, o homem se caracteriza acima de tudo pela superação de uma situação, pelo que ele consegue fazer com o que nós fizemos dele (SARTRE, 1960, p. 85).

\section{Estruturação}

Ao preparar e contar sua história de vida, o narrador nunca diz tudo. Ainda bem, caso contrário, seria perfeitamente inútil. Existe uma grande lacuna entre a vida vivida através de uma multiplicidade de eventos, na qual a única estrutura é a sequência cronológica, e a narrativa desta mesma vida. Nessa diversidade inicial, um tanto confusa e colorida de eventos, o narrador selecionará o que parece significativo, digno de ser dito, e descartará o que não é. Ao fazer isso, ele cria uma primeira modalidade de estruturação ou configuração (RICOEUR, 1983) 
estabelecendo laços de causalidade ou simplesmente de significado comum entre certos eventos que depois assumem um lugar central em sua narrativa, pois assume-se que eles têm um lugar importante no curso da vida. O feedback dos participantes - incluindo o formador - irá frequentemente revisitar e mover esta estruturação inicial. Esta é a função das propostas de "pistas de compreensão da própria história" dadas ao narrador e que ligam elementos da própria narrativa que não apareceram como tal no enunciado inicial. Estas são as conexões da vida (DILTHEY, 1947) que estruturam a narrativa, a visão do narrador da sua trajetória e, em última instância, de si mesmo.

\section{Historicidade}

A historicidade é a capacidade do ser humano, baseada em uma análise reflexiva da sua história passada e de uma consciência das influências que foram exercidas sobre ela, de dar a si mesmo o controle suficiente sobre seu futuro para influenciá-lo. Isto é exatamente o que acontecerá com Fred. Partindo da análise de seu fracasso escolar, que o leva não a uma disposição pessoal de preguiça ou inaptidão intelectual, mas a um valor interiorizado do seu meio de origem, ele se permitirá o que até então havia sido interditado: os estudos universitários e o seu real desejo por eles.

\section{Em direção à individuação coletiva}

Até agora, a ênfase tem sido no que a abordagem "histórias de vida" provavelmente trará a cada participante, individualmente, afirmação e reconhecimento, autorização em termos de construção pessoal. Mas o interesse deste tipo de prática de formação não se limita a estes benefícios individuais. Também afeta o coletivo. Tendo acompanhado cerca de quinze cursos profissionais de animação e de candidatos ao DEFA, eu e meus colegas formadores pudemos comparar os que passaram pelo módulo "histórias de vida" e aqueles que não passaram Observamos que nas formações que tinham trabalhado as histórias de vida, o grupo não era o mesmo nos três anos de duração do curso, diferentemente dos cursos no quais o processo não tinha acontecido. A diferença foi que, no primeiro caso, estávamos lidando com um verdadeiro coletivo de estudantes que estavam solidários e inclinados à cooperação; no segundo, o curso tendia a ser mais uma justaposição de individualidades solitárias. Dito de outra forma, no primeiro caso, um "nós" estava se afirmando, o que era muito menos evidente no segundo. 
A hipótese que levantamos para entender essa diferença é que: a abordagem "história de vida" não envolve apenas processos psico-individuais, mas também processos sociais. Daí a necessidade de usar quadros sociológicos de referência para trabalhar com ela. Tudo o que permite a identificação dos pontos de encontro entre as diferentes narrativas e os elementos característicos das profissões de animação sociocultural e educação popular cabem neste registro. No final, os participantes descobriram que, além das diferenças entre os caminhos profissionais e de vida uns dos outros, eles faziam parte de uma história social comum e de valores compartilhados. Todas as coisas que definem uma individualização coletiva.

Individuação é o "processo pelo qual o diverso em geral, o diverso que sou, assim como o diverso que somos, tende a se unificar e, através dele, tende para a in-divisibilidade do indivíduo, ou seja, a uma pura adequação a si mesmo" (STIEGLER, 2003).

\section{REFERÊNCIAS}

AUSTIN, John Langshaws . Quand dire, c'est faire. Paris: Seuil, 1970.

BOURDIEU, Pierre. Esquisse d'une théorie de la pratique. Paris: Seuil, 2000.

DILTHEY, Wilhelm. Introduction aux sciences de l'esprit. Paris: Aubier, 1947.

FREIRE, Paulo. Pédagogie des opprimés. Paris: Éditions Maspéro, 1974.

FOUCAULT, Michel. Dits et écrits. Tome IV. Paris: Gallimard, 1994.

LEFEBVRE, Henri. Critique de la vie quotidienne: De la modernité au modernisme (pour une métaphilosophie du quotidien). Tome III. Paris: L'Arche, 1981.

MEISTER, Albert. Vers une sociologie des associations. Paris : Éditions ouvrières, 1972.

PAGÈS, Max et al. L'Emprise de l'organisation. Paris: Presses Universitaires de France, 1984.

PEYRE, Marion (dir.). Le Livre noir de l'animation socioculturelle. Paris: L'Harmattan, 2005.

PINEAU, Gaston ; Marie-Michèle. Produire sa vie: Autoformation et autobiographie. Montréal: Éditions coopératives Albert Saint-Martin, 1983. 
LAINÉ, A. A abordagem "Histórias de vida em formação" como superação da dupla armadilha...

RICOEUR, Paul. Temps et récit. Paris: Seuil, 1983.

RICOEUR, Paul. Soi-même comme un autre. Paris: Seuil, 1990.

SARTRE, Jean-Paul. Questions de méthode. Paris: Gallimard, 1960.

STIEGLER, Bernard. Passer à l'acte. Paris: Éditions Galilée, 2003.

Texto recebido em 20/10/2020

Texto aprovado em $02 / 12 / 2020$. 